\title{
Septoria leaf blotch and yellow rust control by: fungicide application opportunity and genetic response of bread wheat varieties
}

\author{
Conceição Gomes*, Rita Costa, Ana Sofia Almeida, José Coutinho, Nuno Pinheiro, João Coco, \\ Armindo Costa, Benvindo Maçãs
}

National Institute for Agrarian and Veterinarian Research, Estrada Gil Vaz, Elvas, Portugal

\section{A B S T R A C T}

\begin{abstract}
Septoria leaf blotch and yellow leaf rust are the most important foliar bread wheat diseases that cause significantly yield losses in Portuguese wheat yield. In the present study, field experiments were conducted during 2013/2014 and 2014/2015 wheat growing seasons to evaluate the effect of a fungicide (Bixafen + Protioconazol) on septoria leaf blotch and yellow rust attacks on bread wheat. This evaluation was accessed by: a) checking the opportunity of fungicide application in two different phenological stages (GS 33-34) and (GS 43-44); b) analyzing the genetic resistance of each variety against the attack of these pathogens; c) finding differences on yield components (thousand kernel weight and grains $/ \mathrm{m}^{2}$ ), grain yield and test weight when fungicide was applied one or two times, during the crop cycle. This study showed that: 1) susceptible varieties, with high levels of coefficient of infection, are beneficed with two fungicide applications, at GS 34 plus GS 47, with increases on yield components, yield/ha and test weight; 2) in moderate resistant varieties, with low levels of coefficient of infection, it is justified a preventive fungicide treatment at GS 34, to control the infectious focus and to protect leaves; 3) resistant varieties don't need a disease control, however, results showed that with two fungicide applications, grain yield and test weight increases significantly.
\end{abstract}

Keywords: Bread wheat; Septoria leaf blotch; Yellow rust; Genetic response

\section{INTRODUCTION}

Bread wheat (Triticum aestivum L.) is an important crop in the Mediterranean region, and is the most consumed cereal in Europe. In Portugal, this specie has accounts for 13\% of total cultivated area with cereals (Anpromis, 2015). The irregularity of climatic factors and the occurrence of diseases are the main constraints to obtain high productions. Septoria leaf blotch caused by Zymoseptoria tritici (Desm.) Quaedvlieg \& Crous, 2011, (syn. Mycosphaerella graminicola/Septoria tritici) and yellow leaf rust caused by Puccinia striiformis f. sp. tritici, are the most important foliar wheat diseases that cause significant yield losses in Portuguese wheat yield, mainly in recent years. The strategies to control both fungi include cultural practices (crop rotation, use of balanced fertilizers, framework of planting dates), use of resistant varieties and fungicide application. Despite of continued efforts to develop cultivars with either disease escape traits or specific diseases resistance genes, fungicides are, currently, the only effective method for controlling these pathogens (Arraiano et al., 2009). The generalized use of chemicals, the harmful effects concerning the environment (pollution on groundwater sheets, negative impact on flora and fauna), the high application costs and the ability of the pathogens to develop characteristics related with several infectious cycles and the realization of a sexual reproduction, causing resilience to its active substances, in particular to triazoles and other demethylation-inhibitors (Ashby, 2011), reducing their efficacy. It is also very important, the proper fungicide dose and the phenological application stage of the crop (if the chemical is applied too early, there is a strong possibility to have late infections, and if it is used too late the damage may have already occurred). The effectiveness of a fungicide shouldn't only be determined in terms of disease control but also by its influence on grain yield and grain quality parameters. Treatments with triazoles

\footnotetext{
${ }^{*}$ Corresponding author:

Conceição Gomes, INIAV - National Institute for Agrarian and Veterinarian Research, Estrada Gil Vaz, Ap. 6, 7350-901 Elvas, Portugal. Phone: 003512948573, Mobile: 351 965146855, E-mail: conceicao.gomes@iniav.pt
} 
and strobilurins have been associated with occasional reductions in grain protein content (Dimmock et al., 2002a; Ruske et al., 2004). On the other hand, a positive effect of fungicide application on grain protein content and on the sodium dodecyl sulphate (SDS) sedimentation test has also been reported (Jordan, 1992).

Zymoseptoria tritici (Quaedvlieg et al., 2011) previously known as Mycosphaerella graminicola/Septoria tritici is the causal agent of septoria leaf blotch, one of the most economically important diseases of bread wheat (Triticum aestivum), durum wheat (Triticum durum) and triticale (Triticosecale Wittmack). In Portugal only the asexual state of fungal life cycle is known; the primary and subsequent infections are caused by pycniospores (from pycnia). The symptoms of infection on wheat leaves are expressed as irregular pale brown necrotic lesions with small dark fungal bodies (pycnidia) inside (Kema et al., 1996). Minimum temperatures of $8^{\circ} \mathrm{C}$ and maximum temperatures between $15^{\circ} \mathrm{C}$ and $25^{\circ} \mathrm{C}$, relative humidity higher than $80 \%$ and long periods of leaf wetness are considered as the optimal environmental conditions to disease development.

Puccinia striiformis f. sp. tritici is the causal agent of yellow rust, causing also important yield losses in wheat. It has also the ability to infect rye, barley and several others grass species. Its name is based on the distinguishing stripe of uredinia that produce yellow colored urediniospores (Roelf et al., 1992). This pathogen infects green parts of cereals and grasses. Infections can happen anytime, from the oneleaf to plant maturity phase if the host plants are still green. Symptoms appear about 1 week after infection. The fungus forms long, yellow to orange colored fine stripes on leaves (usually between veins) and on leaf sheaths, glumes and awns on vulnerable plants. When infection occurs on a leaf, the stripe rust pathogen continues to grow parallel to the leaf axis to produce long stripes. The straight strip formed of pustules is an important distinguishing characteristic of this disease. These strips are formed of tiny rust pustules, called uredia. Each uredium contains thousands of urediniospores (Bux, 2011). Weather moisture, temperature and wind are the three most significant climatic features affecting the epidemics. Moisture is the affecting agent of spore germination, infection, and survival; rain allows dispersing spores and consequently spreading the disease, raindrops release urediniospores either directly or by flapping the rust pustules on the diseased plants. Minimum temperatures between $7^{\circ} \mathrm{C}$ and $10^{\circ} \mathrm{C}$ and maximum temperatures around $14^{\circ} \mathrm{C} / 16^{\circ} \mathrm{C}$ are beneficial to infection. Wind plays a major role in scattering yellow rust (Roelf et al., 1992) and has been a major tool of spreading rust spores over extended areas hosting wheat. There is, also, a strong indication of spore transmission by human travelling, which leads the spread to areas where it was absent. In recent years, the epidemiology and the population genetics of Puccinia striiformis have received great attention because it was spread to new areas where it was previously scarce or absent (Hovmoller et al., 2008). Further, it was recently discovered that Berberis spp. could be an alternative host, which may result in recombination and emergence of novel pathotypes.

Epidemics on wheat have increased worldwide with the emergence of an aggressive strain tolerant to high temperature, which reached North Africa and South France since 2004 and, a multivirulent exotic strain (Warrior) that spread in Western Europe in 2011 (Rebai et al., 2015).

In Portugal, mainly in southern region (Alentejo), the most important growing area of cereal crops, the last two years have been marked by severe yellow rust epidemics that caused important yield losses in bread wheat crop. The majority of cultivars during 2013/2014 season suffered high levels of infection of P. striiformis that hindered the infectious process of Z. tritici. During 2014/2015 growing season, negative temperatures during winter were not favorable to $Z$. tritici spores germination, but the early spring cool and wet environmental conditions, were optimal for P. striiformis infection.

\section{MATERIALS AND METHODS}

Trials location and characterization of the study area Trials were conducted during two consecutive growing seasons (2013/2014 and 2014/2015) at experimental fields of National Institute for Agricultural and Veterinary Research (INIAV) at Elvas, south-central Portugal ( $38^{\circ} 53^{\prime} \mathrm{N}, 7^{\circ} 08^{\prime} \mathrm{w}, 220 \mathrm{~m}$ above sea level). The crops were grown in a vertic-calcaricchromic Cambisol soil under rainfed Mediterranean conditions. The soil of the study site had a sandy loam texture, determined gravimetrically on representative soil samples at $30 \mathrm{~cm}$ depth. The $\mathrm{pH}$, measured using a calibrated $\mathrm{pH}$ meter (ratio $10 \mathrm{~g}$ soil: $25 \mathrm{ml}$ deionized $\mathrm{H} 2 \mathrm{O}$ ), was 8.2. The soil organic matter (SOM), determined by oxidation, was $1.3 \%$.

\section{Wheat germplasm and Z. tritici inoculum}

Five bread wheat commercial varieties from different origins and an advanced breeding line from Portuguese Bread Wheat Breeding Program of INIAV were used (Table 1).

In 2013, the trial was sown on December $10^{\text {th }}$ and in 2014 on December $4^{\text {th }}$. In both growing seasons, the sowing density used was 350 seeds $/ \mathrm{m}^{2}$ and the plants of the trial were inoculated with $Z$. tritici spores to ensure pathogen infection. The inoculum was obtain from leaves of multiples bread wheat, showing typical septoria leaf blotch 
symptoms collected from diverse wheat fields in Portugal during 2012/2013 season, following the procedure of Eyal et al. (1987). With this methodology the potential variability of the spore's infection was guarantee. With respect to P. striiformis, the development of the disease was the result of the natural infection.

\section{Experimental design}

The experiment was arranged as a split split plot design with three replicates, including each one of the six bread wheat varieties in each replication. The plot of each variety, in each replication, was divided into three subplots corresponding to each treatment modality. Each plot size had six rows and an area of $6 \mathrm{~m}^{2}(5 \mathrm{~m} \times 1,2 \mathrm{~m})$. Four inoculations with $Z$. tritici inoculum were made with a weak of interval, being the first one at tillering (GS 29, according to Zadoks et al., 1974) and the last at ear emergence (GS 55-59). Before and after each inoculation (made during the evening), the trial was sprinkler irrigated to create favorable conditions for infection.

Fungicide treatments were: T0 - control plot, no fungicide; T1 - one application of Bixafen + Protioconazole at stem elongation (GS 34); T2 - two applications of Bixafen + Protioconazole -at stem elongation (GS 34) and at booting (GS 47).

Five wheat plants per plot were marked to evaluate septoria leaf blotch and yellow rust and were assessed at two different times: at GS 55 (disease severity at heading) and at GS 75 (disease severity at milk development), except for P. striiformis during 2013/14 growing season in which assessments were made only at heading. The percentage of green leaf area affected by $Z$. tritici was assessed on the upper three leaves: F - flag leaf; F-1 - flag leaf minus one; F-2 - flag leaf minus two and the coefficients of infection (CI) by P. striiformis were determined from field scores assessed on the same upper three leaves, giving the severity using the modified Cobb scale (the percentage of green leaf area affected) along with the variety response; these scores are then converted to CI by multiplying severity by an assigned constant value for the variety response, according to the table below (Table 2; Stubbs et al., 1986). The severity of infection by $Z$. tritici and the CI for P. striiformis (Table 3 and 4) were a result of the average mean of the each three leaves in the five wheat plants.

\section{Grain analysis}

Harvest took place at plant maturity (mid-late June) and total grain yield, yield components and test weight were evaluated.

\section{Statistical analysis}

Statistical analysis was performed on SPSS programme (IBM, version 17.0). ANOVA $(\mathrm{P}<0.05)$ was performed for
Table 1: Origin, growth habit and disease behavior of bread wheat varieties and advanced breeding line

\begin{tabular}{llll}
\hline Varieties & Origin & Growth habit & Disease behavior \\
\hline Nogal & France & Facultative & Moderately susceptible \\
Nabão & Portugal & Spring & Susceptible \\
Badiel & Spain & Spring & Susceptible \\
Roxo & Portugal & Spring & Resistant \\
Artur Nick & Spain & Spring & Resistant \\
TE0205 & Portugal & Spring & Moderately susceptible \\
\hline
\end{tabular}

Table 2: Constant values to measure variety response to calculate the coefficient of infection value

\begin{tabular}{llc}
\hline Variety response & Symbol & Constant value \\
\hline Resistant & $\mathrm{R}$ & 0.2 \\
Moderately resistant & MR & 0.4 \\
Moderately susceptible & MS & 0.8 \\
Susceptible & $\mathrm{S}$ & 1.0 \\
\hline
\end{tabular}

Example: Severity $=40 \%$; Field response $=\mathrm{MS} ; \mathrm{Cl}=40 \times 0.8=32$

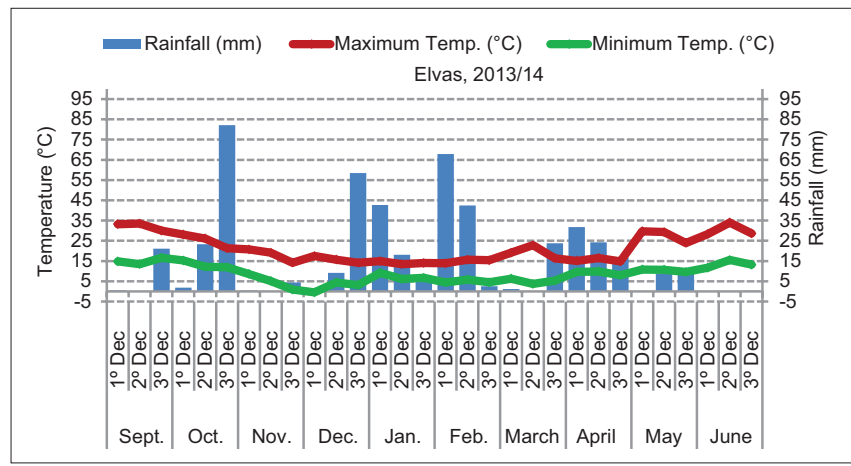

Fig 1. Climate conditions at Elvas during 2013/2014: Monthly periods of ten days with rainfall and maximum and minimum temperatures.

each year, separately, in order to explore specific effects of variety, treatment and variety $\mathrm{x}$ treatment interaction within each year; means comparison were made by Tukey test. Different letters (A, B, C) express significant differences between genotypes.

\section{RESULTS AND DISCUSSION}

\section{Climatic conditions}

Plant Breeding Station at Elvas is located in a climate region characterized by strong Mediterranean influence with high irregularity in precipitation and temperatures among seasons.

During 2013/2014 wheat growing season a total precipitation of $497 \mathrm{~mm}$ occurred and it was distributed during the months with major influence on wheat vegetative and reproductive growth plus the use of a sprinkler irrigated, allowing the hydric comfort to plants. Irrigation did start at end of February until end May, with a total amount of $150 \mathrm{~mm}$. Between January and April (Fig. 1), the minimum temperatures were above $4^{\circ} \mathrm{C}$ and 
Table 3: Severity of infection by $Z$. tritici at heading and milk grain stages and coeffi cient of infection (Cl) of the $P$. striiformis at heading stage (average mean of the each three leaves in the five wheat plants), under each treatment (T0, T1 and T2) during 2013/2014 growing season. *without quantification value

\begin{tabular}{|c|c|c|c|c|c|c|c|}
\hline \multicolumn{8}{|c|}{ TO } \\
\hline & \multicolumn{6}{|c|}{$\%$ leaf area with symptoms of $Z$. tritici } & \multirow{3}{*}{$\begin{array}{c}\mathrm{Cl} \\
\text { (Severity } \times \text { variety response) } \\
\text { Heading }\end{array}$} \\
\hline & \multicolumn{2}{|c|}{$\mathbf{F}$} & \multicolumn{2}{|c|}{ F-1 } & \multicolumn{2}{|c|}{ F-2 } & \\
\hline & Heading & Milk stage & Heading & Milk stage & Heading & Milk stage & \\
\hline Nogal & 5 & 5 & 5 & 5 & 5 & 5 & $8(10 \mathrm{MSS})$ \\
\hline Nabão & 20 & 20 & 30 & 30 & & & 90 (90S) \\
\hline Badiel & & & & * & & & $100(100 S)$ \\
\hline Roxo & 10 & 30 & 40 & 50 & 50 & 55 & 0 \\
\hline Artur nick & 25 & 30 & 30 & 30 & 35 & 35 & 0 \\
\hline TE0205 & 0 & 30 & 5 & 30 & 5 & 30 & 28 (35MS) \\
\hline \multicolumn{8}{|c|}{$\mathrm{T} 1$} \\
\hline Nogal & 0 & 0 & 0 & 0 & 0 & 0 & 0 \\
\hline Nabão & 5 & 5 & 5 & 10 & 5 & 10 & 30 (30S) \\
\hline Badiel & 0 & 35 & 0 & 35 & 5 & 35 & 10 (10S) \\
\hline Roxo & 5 & 25 & 5 & 30 & 10 & 30 & 0 \\
\hline Artur nick & 15 & 30 & 15 & 30 & 15 & 30 & 0 \\
\hline TE0205 & 0 & 20 & 0 & 25 & 0 & 25 & 4 (5SMS) \\
\hline \multicolumn{8}{|c|}{ T2 } \\
\hline Nogal & 0 & 0 & 0 & 0 & 0 & 0 & 0 \\
\hline Nabão & 0 & 5 & 0 & 10 & 5 & 10 & 25 (25S) \\
\hline Badiel & 0 & 20 & 0 & 30 & 5 & 30 & 10 (10S) \\
\hline Roxo & 0 & 5 & 0 & 5 & 0 & 5 & 0 \\
\hline Artur nick & 5 & 15 & 5 & 15 & 10 & 15 & 0 \\
\hline TE0205 & 0 & 10 & 0 & 10 & 0 & 10 & 0 \\
\hline
\end{tabular}

${ }^{*}$ The high $\mathrm{Cl}$ of $P$. striiformis prevented the $Z$. tritici attack

Table 4: Coefficient of infection (Cl) for $P$. striiformis at heading and milk grain stages, (average mean of the each three leaves in the five wheat plants), under each treatment (T0, T1 and T2) during 2014/2015 growing season

\begin{tabular}{|c|c|c|c|c|c|c|}
\hline & \multicolumn{6}{|c|}{$\mathrm{Cl}$ (severityxvariety response) } \\
\hline & \multicolumn{2}{|c|}{ T0 } & \multicolumn{2}{|c|}{ T1 } & \multicolumn{2}{|c|}{ T2 } \\
\hline & Heading & $\begin{array}{c}\text { Milk } \\
\text { stage }\end{array}$ & Heading & $\begin{array}{l}\text { Milk } \\
\text { stage }\end{array}$ & Heading & $\begin{array}{c}\text { Milk } \\
\text { stage }\end{array}$ \\
\hline Nogal & $5(5 S)$ & $10(10 S)$ & 0 & $10(10 S)$ & 0 & 5 (5S) \\
\hline Nabão & $50(50 S)$ & $60(60 S)$ & $10(10 S)$ & $40(40 S)$ & $5(5 S)$ & $15(15 S)$ \\
\hline Badiel & 70 (70S) & 80 (80S) & 20 (20S) & $50(50 S)$ & $5(5 S)$ & 20 (20S) \\
\hline Roxo & 0 & 0 & 0 & 0 & 0 & 0 \\
\hline Artur nick & 0 & 0 & 0 & 0 & 0 & 0 \\
\hline TE0205 & $5(5 S)$ & $5(5 S)$ & $5(5 S)$ & $5(5 S)$ & 0 & 0 \\
\hline
\end{tabular}

the maximum temperatures were mild, with no values exceeding $25^{\circ} \mathrm{C}$. Relative humidity was high in this season. Therefore climate conditions were favourable to infection and germination of spores of $Z$. tritici and P. striiformis and also guaranteed a high severity of diseases during all growing cycle.

In 2014/2015 growing season a total of $533 \mathrm{~mm}$ of rainfall occurred, being irregularly distributed (Fig. 2). The use of sprinkler for complementary irrigation was necessary between the mid February and the first two weeks of May. Total amount of irrigation was $180 \mathrm{~mm}$. The occurrence of negative temperatures resulted on frost formation during nine days in January (Fig. 3). These weather conditions affected the germination of $Z$. tritici spores, which lose their infectivity, and no damage on plants was recorded. In contrast, between the $2^{\text {nd }}$ decade of March and the end of the $1^{\text {st }}$ ten days of May, favorable conditions of humidity and temperatures (minimum and maximum) occurred that were suitable for germination and infection of the fungus P. strifformis, enhanced by the presence of fungal spores and susceptible hosts. This pathogen can germinate until a minimum temperature of $0^{\circ} \mathrm{C}$, reaching the optimum values for the onset of infection between $7^{\circ} \mathrm{C}$ and $12^{\circ} \mathrm{C}$. Rainfall plus irrigation, jointly with periods of cloudiness and humidity, had promoted the progression of the disease.

\section{Disease severity}

Pathogens are capable to develop new types of virulence more and more aggressive able to avoid existing resistance genes in commercial varieties and also with ability to adapt to climate change, resulting in severe outbreaks diseases. The need to find new sources of resistance to the pathogens is crucial, but until it happens, the protection against infections must be based on sustainable application of fungicides. The use of chemical treatments should take into account several factors, such as: time of disease onset, where the fungicide delete the focus of infection and 
Gomes, et al.: Septoria leaf blotch and yellow rust control on bread wheat

Table 5: Yield (kg/ha), thousand kernel weight (g), grains $/ \mathrm{m}^{2}$ and test weight $(\mathrm{kg} / \mathrm{hl})$ during 2013/2014 growing season

\begin{tabular}{|c|c|c|c|c|c|c|c|c|c|c|c|c|c|c|c|c|}
\hline \multirow[t]{2}{*}{ Varieties } & \multicolumn{4}{|c|}{ Yield (kg/ha) } & \multicolumn{4}{|c|}{$\begin{array}{c}\text { Thousand kernel } \\
\text { weight (g) }\end{array}$} & \multicolumn{4}{|c|}{ Grains $/ \mathrm{m}^{2}$} & \multicolumn{4}{|c|}{ Test weight $(\mathrm{kg} / \mathrm{hl})$} \\
\hline & TO & T1 & T2 & & TO & $\mathrm{T} 1$ & T2 & & TO & T1 & T2 & & T0 & T1 & T2 & \\
\hline Nogal & 3706 & 4918 & 5096 & $\mathrm{D}$ & 27,33 & 30,63 & 31,56 & B & 13413 & 16044 & 16148 & $\mathrm{C}$ & 77,67 & 78,75 & 79,50 & C \\
\hline Nabão & 1528 & 3965 & 4898 & B & 22,67 & 27,31 & 29,29 & A & 6553 & 14514 & 16717 & B & 80,67 & 83,01 & 84,05 & $E$ \\
\hline Badiel & 1167 & 4141 & 4977 & B & 24,00 & 35,60 & 37,39 & C & 4782 & 11638 & 13317 & A & 66,00 & 76,46 & 79,23 & A \\
\hline Roxo & 4739 & 5327 & 5375 & $E$ & 29,33 & 33,81 & 34,58 & C & 15954 & 15752 & 15565 & C & 81,67 & 83,30 & 83,46 & $E$ \\
\hline Artur nick & 3439 & 4189 & 4467 & C & 29,00 & 34,18 & 34,59 & C & 11659 & 12193 & 12946 & B & 78,67 & 79,89 & 81,35 & D \\
\hline TE 0205 & 4744 & 5654 & 5883 & $E$ & 37,67 & 40,10 & 42,57 & $\mathrm{D}$ & 12445 & 14135 & 13819 & B & 82,33 & 83,41 & 83,90 & $\mathrm{E}$ \\
\hline Average & 2937 & 4480 & 4776 & & 27,83 & 33,13 & 34,45 & & 10048 & 13528 & 13916 & & 77,42 & 80,20 & 81,21 & \\
\hline Standard deviation & 1397,47 & 881,74 & 800,92 & & 4,55 & 4,20 & 4,11 & & 3913,82 & 2128,72 & 2173,59 & & 5,23 & 2,77 & 2,33 & \\
\hline CV (\%) & 47,59 & 19,68 & 16,77 & & 16,33 & 12,68 & 11,92 & & 38,95 & 15,74 & 15,62 & & 6,76 & 3,45 & 2,87 & \\
\hline Signif. treatment & & $\star \star * *$ & & & & $\star \star *$ & & & & $\star \star \star *$ & & & & *** & & \\
\hline Signif. variety & & $* \star *$ & & & & *** & & & & $\star \star \star *$ & & & & *** & & \\
\hline Signif treat. $x$ variety & & $* * *$ & & & & *** & & & & $* * *$ & & & & *** & & \\
\hline
\end{tabular}

${ }^{* *}$ Stand for significant at the 0.001 level of probability

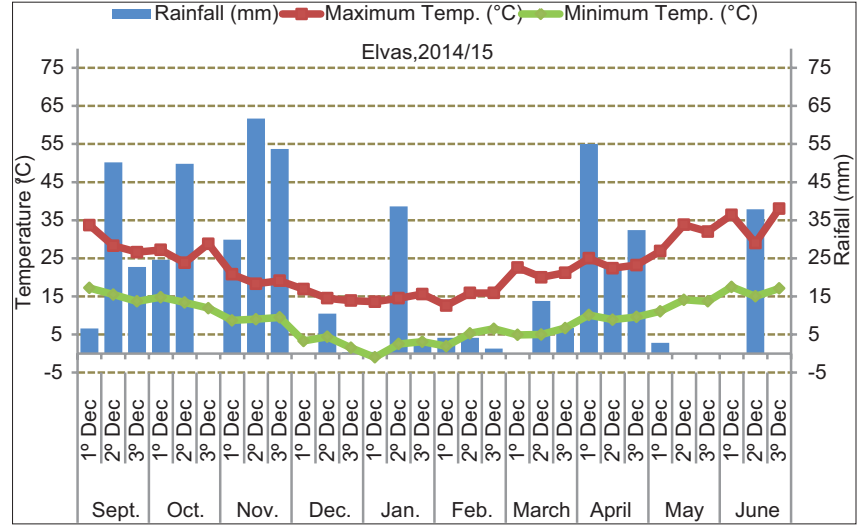

Fig 2. Climate conditions at Elvas during 2014/2015: Monthly periods of ten days with rainfall and maximum and minimum temperatures.

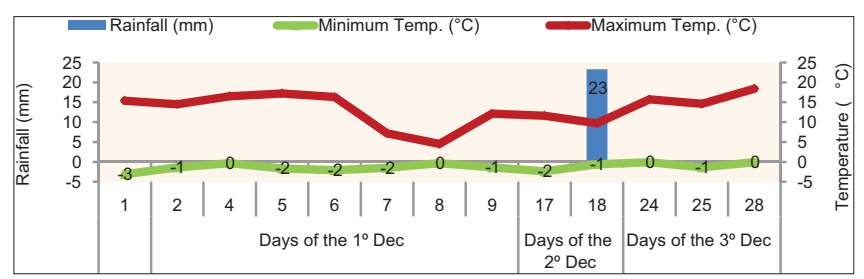

Fig 3. Days of the $1^{\text {st }}, 2^{\text {nd }}$ and $3^{\text {th }}$ decade of January with negative minimum temperatures.

acts as a preventive action, controlling the spreading of spores. Another key point is the ability to identify varieties phenological stage at the moment when disease is detected, and finally, the behavior of varietal genetic susceptibility/ resistance, which helps to choose when and how many fungicide treatments farmers should make to be able to protect their crops.

\section{3/2014 growing season}

For T0 (control plot, no fungicide) (Table 3), varieties showed different genetic behavior over pathogens presence. In consequence of a high CI of $P$. striiformis in
Nabão and Badiel, wasn't possible to visualize the presence of $Z$. tritici infection due the diminutive leaf area available. Roxo and Artur Nick were resistant and Nogal and TE0205 showed moderate susceptibility to $P$. striiformis. Regarding to Z. tritici, Nogal expressed a moderate resistance and the remaining three varieties a moderate susceptibility. With T1 and T2 fungicide treatments, the severity of both diseases decreased, but two applications of Bixafen + Protioconazole at GS 34 plus GS 47, were only justified for attack levels observed in Nabão and Badiel. No differences were found between treatments T1 and T2 to the remaining varieties.

The conventional system of timing applications according to crop growth stage has been subject of several studies. Cook et al. (1999) recognized that fungicides applied during the period from flag leaf emergence (GS 37) to ear emergence (GS 59) offer the best prospect for costeffective foliar disease control.

\section{4/2015 growing season}

In the absence of $Z$. tritici, the study was only focused on the incidence of yellow rust in the genotypes.

For T0, similar to 2013/2014 season, Roxo and Artur Nick showed resistance to yellow rust (Table 4); varieties Nabão and Badiel were the most susceptible to the fungus, showing the highest values to CI. Only in those varieties, the application of two treatments shown to be effective. For Nogal and TE0205 no differences were found between $\mathrm{T} 1$ and T2, however the treatment at stem elongation may has a preventive role against pathogen infection. Burke and Dunne (2008) reported that the conventional system of timing applications according to crop growth stage it is important but also the inoculum development, rainfall distribution, cultivar susceptibility and fungicide activity should be in consideration. 


\section{Grain yield, yield components and test weight} 2013/2014 growing season

Data in Table 5 showed that, for all varieties, grain yield, yield components and test weight increased when the disease is controlled with one or two fungicide applications. Genotypes that showed increased values with two treatments were those that shown to be more susceptible to the fungi, mainly for $P$. striiformis, namely Nabão and Badiel. ANOVA results showed a high significant effect of treatment, variety and treatment $\mathrm{x}$ genotype interaction $(\mathrm{P} \leq 0.1 \%)$ to all parameters.

Test weight is an agronomic parameter that reflects the adaptability of a given variety to the environment, so it was not surprising that when there is a disease control, the values increased for all the genotypes but mainly, for the most susceptible ones, due to the control of this biotic stress.

Photosynthetic activity is the main physiological process responsible of increments in yield. In plants infected with pathogens, there is a decline in photosynthetic activity because of a decrease in photosynthesizing leaf area or a reduction in the efficiency of the process (Yarwood, 1967; Goodman et al., 1986, cit. by Shtienberg, 1990) affecting indirectly the rate and duration of grain weight accumulation (Shtienberg, 1990).

It is important to note that if diseases were controlled by fungicide, a direct benefit can be seen on yield components and, naturally, on final grain yield (Rodrigo et al., 2014). Fig. 4 presents the gains between treatments T0, T1 and T2, on yield components and grain production of each variety. The highest differential values to all of them correspond to the susceptible varieties that had the high coefficient of infection of the fungi (Nabão and Badiel).

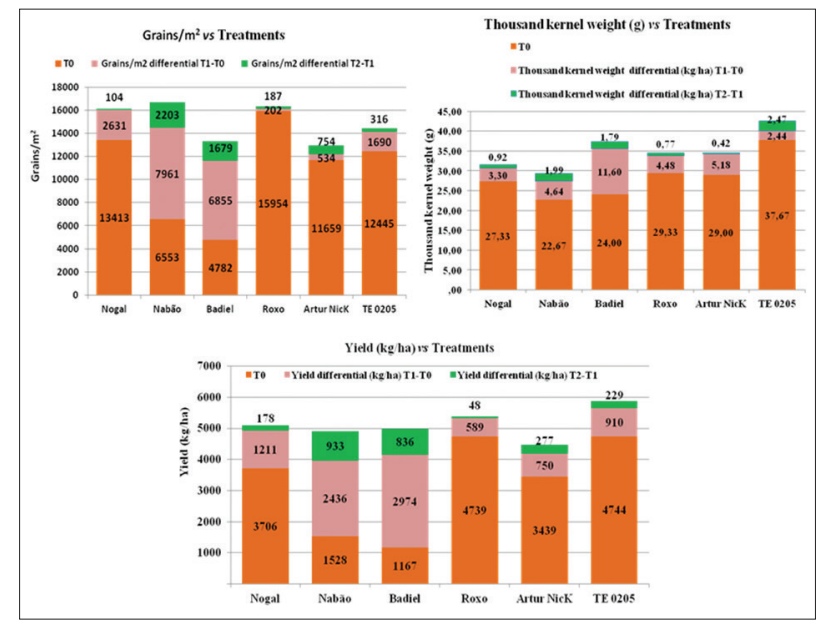

Fig 4. Differential values due to treatment on yield components (grains $/ \mathrm{m}^{2}$ and thousand kernel weight) and final yield during 2013/2014.
As reported by Cook and Thomas (1990), data showed that yield losses of high yield potential varieties were often relatively lower than those recorded for varieties with lower yield potential.

Pearson's correlation coefficients among all these variables for all treatments (Tables 6, 7 and 8) reinforce what was above illustrated. The correlation coefficients between yield and its components were significantly positive.

\section{4/2015 growing season}

Between the $2^{\text {nd }}$ decade of March and the end of $1^{\text {st }}$ decade of May (Fig. 2) the occurrence of $133.6 \mathrm{~mm}$ of rainfall, plus irrigation and the gradual increase of maximum temperatures, which did not reach extreme values (occurrence of heat stress) or "thermal peaks", were very favorable to grain formation and, specially, to grain filling, hence the varieties, even under biotic stress (T0), obtained higher values for yield components, yield, and test weight, than in 2013/2014 (Table 9). As observed

Table 6: Pearsonxs correlation coefficients among grains/ $\mathrm{m}^{2}$, thousand kernel weight $(\mathrm{g})$, yield $(\mathrm{kg} / \mathrm{ha}$ ) and test weight (kg/hl) without fungicide application (TO), during 2013/2014

\begin{tabular}{lcccc}
\hline & Yield & Grains $/ \mathrm{m}^{2}$ & $\begin{array}{c}\text { Thousand } \\
\text { kernel } \\
\text { weight }\end{array}$ & $\begin{array}{c}\text { Test } \\
\text { weight }\end{array}$ \\
\hline Yield & 1 & & & \\
Grains $/ \mathrm{m}^{2}$ & $0,951^{* *}$ & 1 & & \\
Thousand kernel weight & $0,785^{* *}$ & $0,566^{* *}$ & 1 & \\
Test weight & $0,649^{* *}$ & $0,626^{* *}$ & $0,500^{*}$ & 1 \\
\hline
\end{tabular}

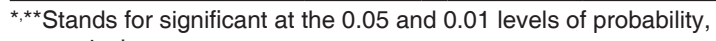
respectively

Table 7: Pearsonxs correlation coefficients among grains $/ \mathrm{m}^{2}$, thousand kernel weight $(\mathrm{g})$, yield $(\mathrm{kg} / \mathrm{ha})$ and test weight (kg/hl) with one fungicide application (T1), during 2013/2014

\begin{tabular}{|c|c|c|c|c|}
\hline 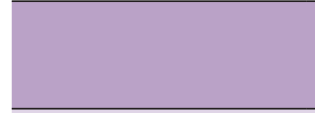 & Yield & Grains $/ \mathrm{m}^{2}$ & $\begin{array}{c}\text { Thousand } \\
\text { kernel } \\
\text { weight }\end{array}$ & $\begin{array}{c}\text { Test } \\
\text { weight }\end{array}$ \\
\hline Yield & 1 & & & \\
\hline Grains $/ \mathrm{m}^{2}$ & $0,760^{* *}$ & 1 & & \\
\hline Thousand kernel weight & $0,626^{* *}$ & $-0,025$ & 1 & \\
\hline Test weight & $0,473^{*}$ & $0,524^{* *}$ & 0,075 & 1 \\
\hline
\end{tabular}

Table 8: Pearsonxs correlation coefficients among grains $/ \mathrm{m}^{2}$, thousand kernel weight $(\mathrm{g})$, yield $(\mathrm{kg} / \mathrm{ha})$ and test weight $(\mathrm{kg} / \mathrm{hl})$ with two fungicide applications (T2), during 2013/2014

\begin{tabular}{lcccc} 
& Yield & Grains $/ \mathrm{m}^{2}$ & $\begin{array}{c}\text { Thousand } \\
\text { kernel } \\
\text { weight }\end{array}$ & $\begin{array}{c}\text { Test } \\
\text { weight }\end{array}$ \\
\hline Yield & 1 & & & \\
Grains $/ \mathrm{m}^{2}$ & $0,713^{\star *}$ & 1 & & \\
Thousand kernel weight & $0,527^{* *}$ & $-0,216$ & 1 & \\
Test weight & $0,473^{*}$ & $0,408^{*}$ & 0,157 & 1 \\
\hline
\end{tabular}

${ }_{*, * *}$ Stands for significant at the 0.05 and 0.01 levels of probability, respectively 
Gomes, et al.: Septoria leaf blotch and yellow rust control on bread wheat

Table 9: Yield (kg/ha), thousand kernel weight (g), grains $/ \mathrm{m}^{2}$ and test weight $(\mathrm{kg} / \mathrm{hl})$ during 2014/2015 growing season

\begin{tabular}{|c|c|c|c|c|c|c|c|c|c|c|c|c|c|c|c|c|}
\hline \multirow[t]{2}{*}{ Varieties } & \multicolumn{4}{|c|}{ Yield (kg/ha) } & \multicolumn{4}{|c|}{$\begin{array}{c}\text { Thousand kernel } \\
\text { weight }(\mathrm{g})\end{array}$} & \multicolumn{4}{|c|}{ Grains $/ \mathrm{m}^{2}$} & \multicolumn{4}{|c|}{ Test weight (kg/hl) } \\
\hline & TO & T1 & T2 & & TO & T1 & T2 & & TO & T1 & T2 & & $\mathrm{S} / \mathrm{TT}$ & $1 / \mathrm{TT}$ & $2 / \mathrm{TT}$ & \\
\hline Nogal & 4748 & 5070 & 5149 & B C & 31,47 & 32,87 & 31,50 & $A$ & 15144 & 15416 & 16328 & CD & 75,36 & 75,33 & 75,31 & $A$ \\
\hline Nabão & 4387 & 5195 & 5365 & B C & 28,00 & 30,97 & 32,77 & $A$ & 15620 & 16765 & 16393 & DE & 77,84 & 80,00 & 81,32 & C D \\
\hline Badiel & 4788 & 6114 & 6610 & D & 36,40 & 40,40 & 42,87 & B & 13154 & 15177 & 15442 & $\mathrm{C}$ & 72,36 & 74,67 & 76,41 & $A$ \\
\hline Roxo & 4846 & 4442 & 4621 & B & 39,97 & 39,73 & 41,33 & B & 12184 & 11213 & 11194 & B & 80,57 & 80,33 & 81,08 & $\mathrm{D}$ \\
\hline Artur nick & 6554 & 6521 & 6686 & $E$ & 39,23 & 39,00 & 40,57 & B & 16700 & 16746 & 16495 & $E$ & 77,41 & 77,00 & 78,17 & B \\
\hline TE 0205 & 6181 & 6466 & 6719 & DE & 45,40 & 45,47 & 44,43 & $\mathrm{C}$ & 13564 & 14224 & 15081 & $\mathrm{C}$ & 79,56 & 79,33 & 79,75 & $\mathrm{C}$ \\
\hline Average & 5251 & 5635 & 5858 & & 36,75 & 38,07 & 38,91 & & 14394 & 14924 & 15156 & & 77,18 & 77,78 & 78,67 & \\
\hline Standard deviation & 887,79 & 853,15 & 923,97 & & 6,26 & 5,32 & 5,43 & & 1702,58 & 2062,84 & 2023,93 & & 2,97 & 2,45 & 2,48 & \\
\hline CV (\%) & 16,91 & 15,14 & 15,77 & & 17,03 & 13,96 & 13,95 & & 11,83 & 13,82 & 13,35 & & 3,85 & 3,16 & 3,15 & \\
\hline Signif. treatment & \multicolumn{4}{|c|}{$* * *$} & \multicolumn{4}{|c|}{$* * *$} & \multicolumn{4}{|c|}{$\star * *$} & \multicolumn{4}{|c|}{$* * *$} \\
\hline Signif. variety & \multicolumn{4}{|c|}{$* * *$} & \multicolumn{4}{|c|}{$* * *$} & \multicolumn{4}{|c|}{$* * *$} & \multicolumn{4}{|c|}{$* * *$} \\
\hline Signif Treat.xvariety & \multicolumn{4}{|c|}{$* * *$} & \multicolumn{4}{|c|}{$\star \star \star *$} & \multicolumn{4}{|c|}{$* * *$} & \multicolumn{4}{|c|}{$* * *$} \\
\hline
\end{tabular}

${ }^{* *}$ Stand for significant at the 0.001 level of probability

in the previous year, variety, treatment and the interaction variety $\mathrm{x}$ treatment were statistically significant $(\mathrm{P} \leq 0.01 \%)$.

Nabão and Badiel were susceptible to P. striiformis (Table 4) but when fungicide was applied at stem elongation or at stem elongation plus booting, yield and all other parameters increased (Table 9). For the moderate susceptible varieties (Nogal and TE0205) and resistant varieties (Roxo and Artur Nick) with lower or without levels of infection, respectively, yield was higher even in the absence of disease control. Even so, Roxo and Artur Nick were more productive with two fungicide applications, which can be attributed to Bixafen + Protioconazole action, that acting at different level of plant physiology, contribute to prolong the duration of the "stay green" leaves and, consequently, benefits photosynthetic activity.

According to Bayer, this behavior may happen, perhaps, not only due to the genetic yielding capacity of the varieties itself but, also, to the result of the intrinsic characteristics of the fungicide (www.research.bayer.com).

These results have some similarity to those obtained by Mercer and Ruddock (2005), that conducted a study with several fungicides applied at a range of doses to winter wheat against foliar diseases. These authors showed an improvement in green leaf area retention and on yield, due to good control of the pathogen, mainly in the susceptible varieties, but no effect with the resistant one. Moreover, on average, maximum profitability with the susceptible genotypes was achieved with a full dose, while with resistant varieties it was with a half dose.

Fig. 5 illustrates what was mentioned earlier, showing the differences obtained for each treatment modality.

Pearson's correlation coefficients for 2014/2015 season without fungicide application (T0) (Table 10), showed
Table 10: Pearsonxs correlation coefficients among grains $/ \mathrm{m}^{2}$, thousand kernel weight $(\mathrm{g})$, yield $(\mathrm{kg} / \mathrm{ha})$ and test weight (kg/hl) without fungicide application (TO), during 2014/2015

\begin{tabular}{|c|c|c|c|c|}
\hline & Yield & Grains $/ \mathrm{m}^{2}$ & $\begin{array}{c}\text { Thousand } \\
\text { kernel } \\
\text { weight }\end{array}$ & $\begin{array}{c}\text { Test } \\
\text { weight }\end{array}$ \\
\hline Yield & 1 & & & \\
\hline Grains $/ \mathrm{m}^{2}$ & $0,784^{* *}$ & 1 & & \\
\hline Thousand kernel weight & $0,415^{\star}$ & $-0,232$ & 1 & \\
\hline Test weight & 0,193 & $-0,067$ & $0,434^{*}$ & 1 \\
\hline
\end{tabular}

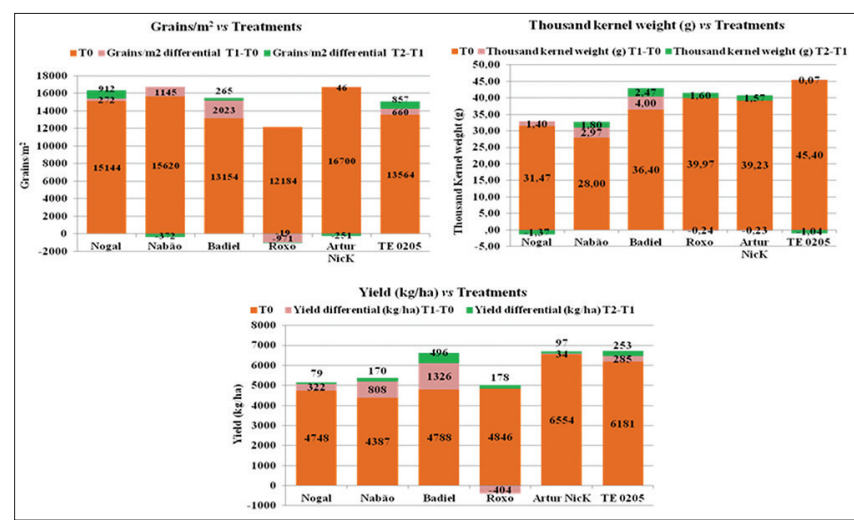

Fig 5. Differential due to treatment on yield components (grains $/ \mathrm{m}^{2}$ and thousand kernel weight) and final yield during 2014/2015.

that yield is higher significantly correlated with grains $/ \mathrm{m}^{2}$ $(\mathrm{P} \leq 0.01 \%)$ than with thousand kernel weight $(\mathrm{P} \leq 0.05 \%)$. Nevertheless when varieties were protected against pathogen infection with one or two fungicide applications (Tables 11 and 12, respectively), only the grains $/ \mathrm{m}^{2}$ was correlated with final grain yield.

\section{CONCLUSIONS}

As regards to $P$. striiformis, the results showed that: 1) susceptible varieties (Nabão and Badiel) with high levels 
Table 11: Pearsonxs correlation coefficients among grains $/ \mathrm{m}^{2}$, thousand kernel weight $(\mathrm{g})$, yield $(\mathrm{kg} / \mathrm{ha})$ and test weight (kg/hl) with one fungicide application (T1), during 2014/2015

\begin{tabular}{lcccc} 
& Yield & Grains $/ \mathrm{m}^{2}$ & $\begin{array}{c}\text { Thousand } \\
\text { kernel } \\
\text { weight }\end{array}$ & $\begin{array}{c}\text { Test } \\
\text { weight }\end{array}$ \\
\hline Yield & 1 & & & \\
Grains $/ \mathrm{m}^{2}$ & $0,751^{* *}$ & 1 & & \\
Thousand kernel weight & 0,169 & $-0,518^{* *}$ & 1 & \\
Test weight & $-0,260$ & $-0,368$ & 0,257 & 1 \\
\hline
\end{tabular}

${ }^{*}$ Stands for significant at the 0.01 level of probability

Table 12: Pearsonxs correlation coefficients among grains $/ \mathrm{m}^{2}$, thousand kernel weight $(\mathrm{g})$, yield $(\mathrm{kg} / \mathrm{ha})$ and test weight (kg/hl) with two fungicide applications (T2), during 2014/2015

\begin{tabular}{lcccc} 
& Yield & Grains $/ \mathrm{m}^{2}$ & $\begin{array}{c}\text { Thousand } \\
\text { kernel } \\
\text { weight }\end{array}$ & $\begin{array}{c}\text { Test } \\
\text { weight }\end{array}$ \\
\hline Yield & 1 & & & \\
Grains $/ \mathrm{m}^{2}$ & $0,653^{* *}$ & 1 & & \\
Thousand kernel weight & 0,223 & $-0,588^{* *}$ & 1 & \\
Test weight & $-0,232$ & $-0,458$ & 0,336 & 1 \\
\hline
\end{tabular}

${ }^{*}$ Stands for significant at the 0.01 level of probability

of coefficient of infection, respond to the application of two treatments, at GS 34 plus GS 47, with increases on yield components, yield/ha and test weight; 2) on varieties showing moderate susceptibility (Nogal and TE 0205) with low levels of coefficient of infection, it is justified a preventive treatment at GS 34, to control the infectious focus and to protect leaves; 3 ) varieties with resistance to this fungi (Roxo and Artur Nick), there is not need for fungicide application to control the disease. Nevertheless, results showed that with two fungicide applications, these varieties significantly increased grain yield and test weight.

The above conclusions also apply in the case of severity by $Z$. tritici, which took place during 2013/2014 growing season.

\section{Authors contributions}

All the authors of the paper contributed equally to the writing of the paper and were involved in the overall planing and supervision of the work.

\section{REFERENCES}

Anpromis. 2015. Available from: http://www.anpromis.pt/images/ dados/catotnac.pdf.

Arraiano, L. S., N. Balaam, P. M. Fenwick, C. Chapman, D. Feuerhelm and P. Howell. 2009. Contributions of disease resistance and escape to the control of Septoria tritici blotch of wheat. Plant Pathol. 58: 910-922.

Ashby, P. 2011. Feedback from the EPPO Septoria tritici azole resistance workshop 2010. Aspects Appl. Biol. 106: 97-101.

Burke, J. J. and B. Dunne. 2008. Investigating the effectiveness of the Thies Clima "Septoria Timer" to schedule fungicide applications to control Mycosphaerella graminicola on winter wheat in Ireland. Crop Prot. 27: 710-718.

Bux, H. 2011. Molecular characterization of wheat stripe rust pathotypes (Puccinia striiformis $\mathrm{f}$. sp. tritici) and their virulence pattern, collected from Pakistan and U.S.A.. A Thesis for the Degree of Doctor of Philosophy (Plant Science). Faculty of Biological Sciences. Islamabad. p. 10-15.

Cook, R. J. and M. R. Thomas. 1990. Influence of site factors on yield response of winter wheat to fungicide programmes in England and Wales, 1979-87. Plant Pathol. 39: 548-557.

Cook, R. J., M. J. Hims and T. B. Vaughan. 1999. Effects of fungicide spray timing on winter wheat disease control. Plant Pathol. 48: 33-50.

Dimmock, J. P. R. and M. J. Gooding. 2002a. The influence of foliar diseases and their control by fungicides on the protein concentration in wheat grain; A review. J. Agric. Sci. 138 349-366.

Eyal, Z., A. L. Scharen, J. M. Prescott and M. van Ginkel. 1987. The Septoria Diseases of Wheat: Concepts and Methods of Disease Management. CIMMYT, Mexico.

Hovmoller, M. S., A. H. Yahyaoui, E. A. Milus and A. F. Justesen. 2008. Rapid global spread of two aggressive strains of a wheat rust fungus. Mol. Ecol. 17: 3818-3826.

Jordan, V. W. L. 1992. Nitrogen and Fungicide Interactions in Breadmaking Wheat. Home-Grown Cereals Authority, London.

Kema, G., D. Yu, F. Rijkenberg, M. Shaw and R. Baayen. 1996. Histology of the pathogenesis of mycosphaerella graminicola pathosystem III. Comparative seedling and adult plant experiments. Phythopathol. 87: 266-272.

Mercer, P. C. and A. Ruddock. 2005. Disease management of winter wheat with reduced doses of fungicides in Northern Ireland. Crop Prot. 24: 221-228.

Quaedvlieg, W., G. H. J. Kema, J. Z. Groenewald, G. J. M. Verkley, S. Seifborghi, M. Razavi, M. A. Gohari, R. Mehrabir and W. Crous. 2011. Zymoseptoria gen. nov.: A new genus to accommodate Septoria-like species occurring on graminicolous hosts. Persoonia Mol. Phyl. Evol. Fungi. 26: 57-69.

Rebai, H., M. Leconte, S. Hamza, C. Vallavielle-Pope and B. Bochra. 2015. Yellow rust pathotypes and resistance gene postulations in Tunisian wheat. In: Proceedings of the $14^{\text {th }}$ International Cereal Rusts and Powdery Mildews Conference. Publisher European and Mediterranean Cereal Rusts Foundation, p. 78.

Rodrigo, S., B. Cuello-Hormigo, C. Gomes, O. Santamaria, R. Costa, M. J. Poblaciones. 2014. Influence of fungicide treatments on disease severity caused by Zymoseptoria tritici, grain yield and quality parameters of bread-making wheat under mediterranean conditions. Eur. J. Plant Pathol. 141: 99-109.

Roelfs, A. P., R. P. Singh and E. E. Saari. 1992. Rust Diseases of Wheat: Concepts and Methods of Diseases Management CIMMYT, Mexico, D. F., p23-27.

Ruske, R. E., M. J. Gooding and D. J. Dobraszczyk. 2004. Effects of triazole and strobilurin fungicide programmes, with and without late-season nitrogen fertilizer, on the baking quality of Malacca winter wheat. J. Cereal Sci. 40: 1-8.

Shtienberg, D. 1990. Effect of foliar diseases of wheat on the physiological processes affecting yield under semi-arid conditions. Plant Pathol. 40: 533-541.

Stubbs, R. W., J. M. Prescott, E. E. Saari and H. J. Dubin. 1986. Cereal Disease Methodology Manual. CIMMYT, Mexico, Pp. 21-23.

Zadocks, J. C., T. T. Chang and C. F. Konzak. 1974. A decimal code for the growth stages of cereals. Weed Res. 14: 415-421. 